This is the accepted version of an article published in Quaternary

International vol 382

doi: 10.1016/j.quaint.2015.01.005

\title{
Orbital-Scale Climate Variability in Arabia as a Potential Motor for Human Dispersals
}

\author{
Ash Parton ${ }^{a}$, Tom S. White ${ }^{a}$, Adrian G. Parker ${ }^{b}$, Paul S. Breeze ${ }^{c}$, Richard \\ Jennings ${ }^{a}$, Huw S. Groucutt ${ }^{a}$, Michael D. Petraglia ${ }^{a}$
}

\begin{abstract}
${ }^{a}$ School of Archaeology, Research Laboratory for Archaeology and the History of Art, University of Oxford, Oxford, OX1 2HU, United Kingdom.

${ }^{b}$ Human Origins and Palaeoenvironments (HOPE) Research Group , Department of Social Sciences, Oxford Brookes University, Headington, Oxford OX3 OBP, UK.
\end{abstract}

${ }^{c}$ Department of Geography, King's College London, UK.

\begin{abstract}
The Arabian Peninsula is situated at an important crossroads for the movement of Pleistocene human populations out of, and into, Africa. Although the timings, routes and frequencies of such dispersals have not yet been confirmed by genetic, fossil or archaeological evidence, expansion into Arabia would have been facilitated by humid periods driven by incursions of monsoon rainfall, potentially from both Indian Ocean and African monsoon systems. Here we synthesise terrestrial and marine core palaeoclimatic data in order to establish the spatial and temporal variability of humid periods in Arabia between late Marine Isotope Stage (MIS) 7 and 3. Incursions of monsoon rainfall occurred during periods of insolation maxima at ca. 200-190, 170, $155,130-120,105-95,85-75$ and 60-55 ka, providing multiple 'windows' of favourable climatic conditions that could have facilitated demographic expansion through Arabia. Strong summer monsoons are generally associated with mid-high latitude interglacials, however, enhanced monsoon convection also brought rainfall into Arabia during global glacial phases, possibly due to a strengthened winter monsoon and a greater influence of southern hemispheric temperature changes. Key periods for dispersal into northern regions of Arabia correspond with the synchronous
\end{abstract}


intensification of both eastern Mediterranean and monsoon rainfall systems at insolation maxima during MIS 7 and MIS 5, which may have facilitated demographic connectivity between the Levant and the Arabian interior. Environmental conditions throughout southern and southeast regions were also favourable to expansion during these times, although strong monsoons in these regions during MIS 6 and MIS 3 suggest further opportunities for demographic expansion and exchange. Terrestrial and marine evidence show that during early MIS 3 (ca. 60-50 ka), a strengthened monsoon led to the activation of interior drainage systems and increased productivity in coastal zones, indicating that favourable environmental conditions existed along both coastal and interior routes at that time.

Keywords: Arabian Palaeoclimate, Human Dispersals, Monsoons, Insolation

\section{Introduction}

The effects of climatic variability continue to play a key role in debates concerning the adaptation and development of human populations both past and present. At the macro scale, climatic and environmental change have been linked to hominin diversification, speciation, extinction and migration events (e.g. Foley, 1994; Trauth, 2007; Shea, 2008; Grove, 2011; 2012), and although direct causal links between evolutionary and climatic 'events' remain unresolved, the demography of hominin populations would undoubtedly have been influenced by climatic and environmental change. Arguably one of the places in which such changes would have been most pronounced is the Arabian Peninsula. Situated at the interface of the mid-latitude Westerlies and African-Indian Ocean Monsoon systems, periodic incursions of increased rainfall associated with these systems have episodically transformed Arabia into a heterogeneous landscape comprised of large freshwater lakes and wetland areas surrounded by extensive grasslands. While this notion of a periodically 'green' Arabia is now generally accepted, given the scale and latitudinal range of the Peninsula, during humid periods the landscape would have still exhibited a variety of bioclimatic zones, making some regions more conducive to subsistence than others. As such, it is important to move beyond a simplistic 'wet vs. dry' dichotomy when assessing the suitability of Arabia for occupation through time, by examining a spatially and 
temporally broad range of both terrestrial and marine palaeoclimatic indicators that reflect the spatio-temporal complexity of the Arabian palaeoclimatic record.

The early dispersals of Homo sapiens out of Africa during Marine Isotope Stage (MIS) 5 (ca. 130-75 ka) indicates that populations were able to expand into the previously arid/hyper-arid Saharo-Arabian desert belt during humid periods. This may be corroborated by the growing number of archaeological sites in the desert interior of Arabia dated to this period (e.g. Armitage et al., 2011; Petraglia et al., 2011; 2012; Rose et al., 2011; Groucutt and Petraglia, 2012; Groucutt et al., 2014, this issue a,b; Scerri et al., 2014, this issue), which are themselves indicators of increased humidity; during arid climatic conditions there is insufficient surficial freshwater to sustain human and animal populations in these regions. Proponents of a later rapid coastal dispersal at ca. 60-50 ka (e.g. Mellars, 2006; Mellars et al., 2013) have disregarded the climate changes of Arabia for this period, however, both coastal and interior zones would have been greatly influenced by monsoon variability. Numerous marine records have shown that seasonal productivity changes in the south Arabian coastal zone have been intimately tied to monsoon-driven upwelling over the past ca. 150 thousand years ago (i.e. Prell and Van Campo, 1986; Leuschner and Sirocko, 2003).

The timing of humid periods in Arabia has been broadly established through both marine and terrestrial records, although discrepancies between these sets of archives have become apparent. Terrestrial records (predominantly lakes and speleothems) have indicated that significant intensifications of the monsoon system occurred at ca. 130-120 ka (MIS 5.5), ca. 105-95 ka (MIS 5.3), ca. 85-75 ka (MIS 5.1) and during the early Holocene (ca. 11-6 ka; e.g. Burns et al., 1998; Fleitmann et al., 2011; Rosenberg et al., 2012; Lézine et al., 2007), with a long arid period between MIS 5 and the early Holocene believed to be too hostile for demographic expansion (Rosenberg et al., 2012). Marine records, however, indicate that increases in monsoon intensity have been far more frequent, corresponding with insolation maxima every ca. 23 thousand years (e.g. Clemens and Prell, 2003; Zeigler et al., 2010a; Caley et al., 2011a). The paucity of evidence in the terrestrial record for major wet phases between MIS 5 and the Holocene has led some researchers to suggest that glacial boundary conditions drive monsoon variability, with expansion of the major ice sheets supressing the northward movement of the Inter Tropical Convergence Zone (ITCZ) and associated monsoon belt (Fleitmann et al., 2009; Rosenberg et al., 2012). Conversely, evidence from marine records appears to show a strong coherence 
between monsoon variability and orbitally driven insolation changes, with monsoon intensity increasing during both northern hemispheric glacial and interglacial periods. Additionally, the extent to which westerly-derived rainfall periodically extended southwards into the Arabian interior during glacial periods is also poorly understood. These contradictions, combined with a tendency to frame Arabian terrestrial records in accordance with northern hemispheric global ice volume patterns, have inhibited our understanding of early demographic expansions into the peninsula.

In order to address these issues, we present an overview of the modern climatic setting of Arabia, together with a synthesis of critical aspects of terrestrial and marine records from in and around the peninsula, in order to develop a framework of palaeoclimate variability. This synthesis focuses on the period between MIS 7 and early MIS 3, as this interval encompasses three critical periods in the development of human populations: i) the emergence of Homo sapiens in Africa by ca. $200 \mathrm{ka}$; ii) the dispersal of human populations out of Africa and into the Levant at ca. 130-90 ka; and iii) the expansion of populations into Asia at ca. 60-45 ka. Rapidly emerging evidence, particularly of glacial-phase climatic complexity in Arabia, highlights the requirement for an updated palaeoclimatic framework for the peninsula for these key periods, which will help shed new light on human demography in the region.

\section{The Arabian Climate}

\subsection{Modern Climatic Setting}

The climate of the Arabian Peninsula results from the complex interaction of several atmospheric systems. The greater monsoon system, which stretches from the Atlantic coast of West Africa across the Arabian Sea and Asia to northern Australia, conveys energy and affects climate on a global scale (Clift and Plumb, 2008). Monsoonderived rainfall is at present limited to the southernmost regions of the Arabian Peninsula, with the Yemen Highlands and Asir Mountains of Saudi Arabia receiving up to $1000 \mathrm{~mm}$ of annual rainfall (Parker, 2009). This seasonally reversing annual system is driven by a land-sea thermal contrast and incoming solar radiation (insolation) changes. During the summer, increased surface heating of the Eurasian landmass in response to greater insolation draws the intertropical convergence zone (ITCZ) and associated monsoon belt northward to a position more than $12^{\circ}$ away from the equator (Fig. 1). This latitudinal shift of the ITCZ is accompanied by the development of a monsoon trough of intense horizontal wind shear extending from 
the Rub al-Khali to the Tibetan Plateau (McGregor and Nieuwolt, 1998), with a resultant southwesterly wind regime. A corresponding high-pressure system, the Mascarene High, occurs simultaneously across much of the southeast Indian Ocean (Krishnamurti \& Bhalme, 1976) and is typified by a large outflow of northwardmoving air. Once across the equator, this outflow (the cross-equatorial Findlater, East African or Somali Jet) becomes a south-westerly, splitting into two branches at around $10^{\circ} \mathrm{N}, 60^{\circ} \mathrm{E}$, and reaching maximum intensity between June and August (Findlater, 1969; McGregor and Nieuwolt, 1998), turning anticyclonically to sweep over parts of Arabia and India (Boos and Emanuel, 2009). Not only does this remarkably stable, moisture-laden jet bring significant volumes of precipitation to the Indian sub-continent, it also gives rise to intense upwelling of cold, nutrient-rich water along the coasts of Yemen and southern Oman, coincident with convergent downwelling in the central and eastern parts of the Arabian Sea (e.g. Nair et al., 1989; Honjo and Weller, 1997; Rixen et al., 2000, 2005; Prasanna Kumar et al., 2001; Sambrotto, 2001).

In addition to monsoon-sourced rainfall, the Arabian Peninsula is also affected by mid-latitude Westerlies (MLW) that originate in the eastern Mediterranean (Enzel et al., 2005) and progress across the Arabian Gulf during the winter months, causing enhanced cyclogenesis throughout the eastern Mediterranean, Red Sea, southern Iran and northern Arabia (i.e. Eshel \& Farrell, 2000; Stevens et al., 2001; Arz et al., 2006). Deep depressions from the eastern Mediterranean may penetrate as far southeastward as eastern Saudi Arabia (Barth and Steinkohl, 2004) and central Oman (Weyhenmeyer et al., 2000). This northwestern source of rainfall constitutes some 40$50 \%$ of the total precipitation of northern Arabia (Fisher \& Membrey, 1998). Anticyclonic circulation around a semi-permanent high pressure cell over northern Arabia, combined with cyclonic circulation around the Asian low pressure system, also gives rise to low-level winds known as the Shamal (Edgell, 2006). These blow northwest to southeast down the Arabian Gulf, before changing direction to cross the Rub' al-Khali (Glennie and Singhvi, 2002), reaching their peak during the summer months and transporting high volumes of aeolian material towards the Arabian Sea (Sirocko et al., 1991). Although the extension of MLW rainfall into southeastern regions of Arabia is aided by the convection of moisture from the Gulf, a strong precipitation gradient exists between the northern Levant and the southern Negev, where annual rainfall decreases from $>1000 \mathrm{~mm}$ to $<50 \mathrm{~mm}$ respectively (Vaks et al., 
2006). Central regions of Arabia are also influenced by a synoptic system known as the Red Sea Trough (RST); a low-level pressure trough that extends from the African Monsoon zone and across the Red Sea towards northwestern regions of Arabia (Morcos, 1970; Patzert, 1974; Pedgley, 1974; Jiang et al., 2009; Almazroui, 2011; Almazroui et al., 2012; Vries et al., 2013), and which delivers infrequent precipitation during the autumn. To date, the palaeoclimatic history of Arabia has been predominantly viewed within the context of monsoonal and, to a lesser extent, westerly rainfall incursions. Consequently, little consideration has been given to the effects of the interaction between these atmospheric systems. However, it is the regional effects of such interactions that have determined the palaeoenvironmental history of Arabia and perhaps, by extension, the potential for inter-regional movements by human populations.

\section{(FIGURE 1 HEREABOUTS)}

\subsection{Long-Term (Orbital-Scale) Monsoon Variability}

A growing number of palaeoclimatic records and palaeoclimate models attest to the periodic spatial variability of these rainfall-bearing systems over the past ca. 245 thousand years. Although there is continuing debate regarding the extent to which enhanced westerly convection during mid-high latitude glacial periods penetrated the Arabian interior (e.g. Petit-Maire, 2010; Rosenberg et al., 2013; Jennings et al., this issue), the effects of monsoon incursions are reflected in numerous archives. Largescale cycles in monsoon variability are driven by the complex interaction of external and internal feedback mechanisms, however, the motors of monsoonal change that have the lowest frequency and the highest magnitude are those related to earth-sun geometry. Changes in the Earth's orbital parameters over ca. 23,000 year (precession), ca. 41,000 year (obliquity) and ca. 100,000 year (eccentricity) periods have affected the intensity and distribution of incoming solar radiation, which in turn has amplified or dampened seasonal monsoon circulation. More broadly, summer monsoon circulation was weaker during Northern Hemisphere glacial periods, while winter monsoons and westerly convection are thought to have become strengthened (e.g. Rohling et al., 2009).

Over the last three decades, several Ocean Drilling Programme (ODP) coring projects dedicated to reconstructing monsoon variability have been undertaken. Cores 
retrieved from the tectonically active Makran margin and Owen Ridge (Fig. 2) have provided insights into the evolution of the Indian Ocean Monsoon system, either directly through various palaeontological and geochemical proxies or through subsequent stacking and modelling of these proxy data (e.g. Prell et al., 1989; 1991; 1992; Murray and Prell, 1991; Clemens et al., 1991; 1996; Prell and Kutzbach, 1992; Sirocko et al., 1999; Leuschner and Sirocko, 2000; 2003; Clemens and Prell, 2003; Clemens et al., 2008; 2010; Ziegler et al., 2010; Caley et al., 2011a; 2013). Additionally, marine cores retrieved from the Red Sea and Eastern Mediterranean enable the reconstruction of African Monsoon variability. Of particular importance is the formation of sapropels in the Mediterranean, which represent large northward shifts and intensity increases of the African Monsoon corresponding to insolation maxima. Influxes of freshwater from the African margin into the Mediterranean induced the collapse of deepwater formation and the development of anoxic conditions which, in turn, resulted in the formation of black, organic-rich sapropel layers (Rohling, 1994). These have provided important information regarding potential dispersal pathways for animals and humans through the Sahara Desert belt (Drake et al., 2011; 2013).

Despite this wealth of data and the development of numerous global climate models (GCM), the precise response of the greater monsoon system to combined boundary conditions such as insolation, ice-volume and greenhouse gases remains uncertain. The extent to which it is in phase at the precession or obliquity bands is also controversial (e.g. Anderson and Prell, 1993; Altabet et al., 1995; Rostek et al., 1997; Reichart et al., 1998; Clemens and Prell, 2003; Clemens et al., 2010; Ziegler et al., 2010; Caley et al., 2011a). Recently, research has suggested that the component African, East Asian and Indian Ocean Monsoon systems respond differently to external and internal forcing mechanisms over millennial timescales (e.g. Caley at al., 2011a; 2011b). While humid periods in Arabia have historically been associated with the incursion of rainfall from an Indian Ocean source (e.g. Burns et al., 1998; Fleitmann et al., 2003; 2004; 2007), recent findings have suggested that previous humid periods in southern, western and central regions of the peninsula may have been attributable to African Monsoon rainfall (Herold and Lohmann, 2009; Rosenberg et al., 2013; Jennings et al., this issue). If this is the case, then temporal/spatial differences between the East African and Indian Ocean monsoon systems (cf. Caley et al., 2011b) may have affected early dispersals into Arabia. 
Importantly, southern hemisphere climate changes during glacial periods may also drive monsoon variability (Caley et al., 2011b). A long-established paradigm has dictated that, as ice sheets shrink and evaporation increases over the Indian Ocean, the monsoon system intensifies through a mechanism described as a 'northern pull' (Rohling et al., 2009). Monsoon variability has, therefore, been predominantly considered as a teleconnective response to northern hemispheric climate changes. However, during glacial phases the Indian Ocean Summer Monsoon (IOSM) may also be influenced by a distinct 'southern push', as the cross-equatorial Somali Jet transports moisture from the South Indian Ocean into the IOSM region (Liu et al., 2011). Indeed, an IOSM Index developed by An et al., (2011) indicates that monsoon minima occurred some 20 ka prior to glacial maxima, and even began to strengthen prior to global ice volume maxima. A possible explanation is that internal climate forcing (i.e. decreased ice volume, increased cross-equatorial latent heat transport) set the timing of strong monsoons, whilst increased insolation acts as the initial trigger for increased monsoonal circulation (Caley et al., 2011b). As such, southern hemispheric temperature changes may drive the IOSM during glacial periods, while the northern hemisphere plays a dominant role during deglaciations (e.g. Banakar et al., 2010; Liu, 2011; Caley et al., 2013).

The records summarized above have important implications for the timing and routes of human dispersals into and through Arabia. Differences in the periodicity, intensity and spatial distribution of monsoon rainfall sources over millennial timescales, would have made certain habitable zones and routes through the peninsula more favourable than others at various times. Importantly, the findings suggest that if an insolation-driven monsoon has played a dominant role in the climate evolution of Arabia over the past ca. $245 \mathrm{ka}$, then 'windows' for dispersal may have been possible every $\sim 23 \mathrm{ka}$, in line with insolation maxima. The incursion of monsoon precipitation into Arabia during glacial periods may have provided further opportunities for human population expansion, challenging the view that a coastal route was the only option during these times, and illustrating a potential critical influence upon Arabian demography which has received little prior attention.

FIGURE 2 HEREABOUTS

\subsection{The Arabian Palaeoclimate Record}


While marine records exhibit a close relationship between monsoon variability and insolation, terrestrial palaeoclimate records from much of Arabia are largely viewed within the context of glacial-interglacial cycles. This dichotomy is understandable; the Pleistocene terrestrial record in Arabia consists of a limited suite of fragmentary, often temporally discontinuous and spatially dispersed palaeoenvironmental archives. In contrast, marine archives provide generally continuous sedimentary records over long timescales. Unfortunately, there are as yet no deep terrestrial sedimentary sequences reported from the Arabian interior that can be closely correlated with these marine records, or from which age-depth models can be created, based on chronostratigraphic proxies. A broader synthesised framework of landscape responses to climate change, using records derived from a range of landforms is therefore required, if we are to understand the way in which palaeoclimatic conditions may have favoured human dispersals. Findings from the key palaeoclimate records discussed in the following sections (locations shown in Fig. 2) are illustrated in Figure 3, with records discussed by region (e.g. southeast Arabia, Red Sea etc.).

\subsection{MIS 7 (ca. 245-185 ka)}

The global climate of MIS 7 was marked by high amplitude insolation variability, in response to large oscillations in the precessional band. These comprised five alternating 'warm' and 'cold' periods, with peak interglacial conditions occurring during MIS 7.1 at ca. 200-185 ka. MIS 7 humid periods associated with northern hemispheric warming are relatively well represented in marine records from the Arabian Sea (Fig. 3), which indicate the occurrence of a strong monsoon at ca. 240, 210 and 200-185 ka. Foraminiferal assemblage and bromine increases in cores from north and south of the Arabian Sea (Des Combes et al., 2005; Ishikawa and Oda, 2007; Ziegler et al., 2010; Caley et al., 2011a), reveal marked increases in wind strength and the development of upwelling along the coast of Oman and Yemen, in response to an intensified and northwardly displaced Indian Ocean Summer Monsoon. These periods correspond with a reduction in terrigenous influx into the Arabian Sea (reduced continental aridity) and coincide with precession-driven insolation maxima (Fig. 3). While individual marine proxies exhibit this trend, however, stacked summer monsoon records (Clemens and Prell, 2003) do not record monsoon intensification during MIS 7.1, which may be due to a smoothing of the stacked signal (Caley et al., 2013). 
Understandably, the terrestrial palaeoclimate record for MIS 7 in Arabia is less clear, however, several records confirm the incursion of summer monsoon rainfall. Speleothem records from Yemen and southern Oman (Fleitmann et al., 2003; 2011) verify the northward intrusion of intensified rainfall during MIS 7, with $\delta^{18} \mathrm{O}$ calcite values confirming a southerly monsoonal moisture source. However, variability between these records suggest that during MIS 7.5, monsoon rainfall did not reach as far north as Hoti Cave, while no speleothem growth is recorded at either site during MIS 7.3. This discrepancy likely indicates that precipitation during these periods was below 300-350 mm yr, and as such, insufficient to recharge the karst aquifers at these sites (Fleitmann et al., 2011). This notion is supported by weighted means of ages for alluvial fan aggradation recorded in the interior of Oman, which reveal drainage activation in line with monsoon maxima at ca. $216 \mathrm{ka}$ (Blechschmidt et al., 2009), and confirm an incursion of monsoon rainfall at this time.

Within the southern Red Sea region, surface water mixing and dust input was reduced during MIS 7, with generally lower productivity, higher oxygen concentrations and increased deepwater formation during higher sea levels (Hemleben et al., 1996; Badawi et al., 2005). This reflects an improved exchange of seawater masses through the Bab el Mandeb, following the eustatic sea level rise of the Red Sea and the increased ventilation of bottom waters attributed to an intensified monsoon (Badawi, 2014). No MIS 7-age terrestrial records currently exist from the central Arabian interior; however, lake and palaeosol formation is reported in the western Nefud during MIS 7 (Petraglia et al., 2012; Rosenberg et al., 2013). Unfortunately, associated errors with ages derived from both sites prevent their assignation to specific MIS sub-stages (wet phases); however, there is some overlap with the MIS 7.3 wet phase reported in other records. Lake formation in the Nefud at this time may have been driven by rainfall from an African source, possibly aided by the extension of convection associated with an enhanced convection through the Red Sea region. Certainly, sapropel deposition in the eastern Mediterranean (S9-7) reflect intensifications of the African Monsoon throughout MIS 7, and the periodic advancement of the ITCZ across the Saharo-Arabian desert belt during times of insolation maxima.

Records of rainfall from speleothems in the Negev Desert demonstrate periods of higher rainfall during MIS 7 (Vaks et al., 2006; 2010), but with a strong northsouth precipitation gradient. During Negev Humid Period 2 (NHP-2) ca. 220-190 ka, 
rainfall decreased between the northern and southern Negev, while no speleothem growth was recorded during MIS 7 in southernmost regions, which are located near to the present-day $300 \mathrm{~mm}$ isohyet (Vaks et al., 2006; 2010). This implies that the southward displacement and intensification of moisture from the eastern Mediterranean during MIS 7 did not extend beyond the southern Negev into Arabia. Unlike speleothem records from southern Arabia, no growth was recorded anywhere within the Negev during MIS 7.5, with NHP-2 itself comprising a series of humid events interspersed by long periods of drought. While no speleothem growth is reported from Soreq Cave (central Israel) during MIS 7, records from Peqiin Cave in northern Israel confirm an intensification of rainfall in the eastern Mediterranean region during MIS 7 substages 7.5, 7.3 and 7.1, and in close correspondence with sapropels 9-7 (Bar-Matthews et al., 2003). While speleothem evidence from the southern Negev may appear to delimit the southward extension of rainfall from the eastern Mediterranean, there is some overlap with age estimates derived from palaeolake Mudawwarra in southern Jordan/northern Saudi Arabia (Petit-Maire et al., 2010). Here, a large depression may have been at least partly occupied by a perennial water body during MIS 7.1, although associated errors of this age may equally reflect an early MIS 6 age. Whilst the site presently lies south of the $300 \mathrm{~mm}$ isohyet threshold for speleothem formation, it is possible that lake formation was attributable to a combination of African Monsoon and Mediterranean rainfall (Petit-Maire et al., 2010), perhaps aided by a substantial catchment area that extends to the southern Jordan highlands. This suggests, therefore, a chronologically synchronous relationship between strengthened eastern Mediterranean cyclones and African Monsoon rainfall during MIS 7 humid periods, bringing wetter conditions to both northern and southern Saharan-Arabian Deserts (Vaks et al., 2010; 2013).

\section{2. $\operatorname{MIS} 6(\mathrm{ca} .185-130 \mathrm{ka})$}

The global climate transition from MIS 7 to MIS 6 was marked by an abrupt cooling period ca. $185 \mathrm{ka}$ (Robinson et al., 2002), which signified the onset of global glacial conditions and the lowering of global sea levels by up to $120 \mathrm{~m}$ (Rabineau, et al., 2006). Within lower latitudes, however, the periodic intensification of the monsoon and westerly systems produced patterns of increased humidity that do not conform to simplistic glacial-interglacial climate signals. Records from the eastern Mediterranean indicate a period of increased rainfall at ca. $175 \mathrm{ka}$ (MIS 6.5), marked by the 
deposition of the S6 sapropel and the intensification of African Monsoon rainfall in response to insolation maxima (Tisserand et al., 2009). The orbital configuration of this period is associated with strong northern hemispheric insolation equivalent to 7.5\% higher than at present (Masson et al., 2000). During this period, slightly wetter conditions persisted throughout the Mediterranean; although, pollen and faunal assemblages remain typical of glacial periods (Rossignol-Strick, 1983; Bard et al., 2002). At Soreq Cave, however, $\delta^{18} \mathrm{O} / \delta^{13} \mathrm{C}$ values of speleothems at ca. $178 \mathrm{ka}$ are reminiscent of interglacial values indicating a concordant intensification of monsoonal and eastern Mediterranean rainfall (Bar-Matthews et al., 2000; Ayalon et al., 2002). Indeed, speleothem growth in the northern Negev at Tzavoa Cave (Vaks et al., 2006) remained continuous between ca. 190 and $160 \mathrm{ka}$, driven by a higher P/E ratio indicating a southward migration of the desert boundary and the emplacement of a Mediterranean climate regime throughout the region. A further period of increased humidity and hydrologic activity is recorded in speleothems from the Levant at ca. 152 ka (Ayalon et al., 2002; Bar-Matthews et al., 2003), and although no sapropel formation is recorded at this time, again this period corresponds to a phase of insolation maxima. This later humid period is also recorded in the central Negev, although only at one site, and with no more than $\sim 200 \mathrm{~mm}$ of annual rainfall (Vaks et al., 2010). Importantly, speleothem records from the Negev indicate that even during monsoon/insolation minima, northern regions remained relatively humid during midhigh latitude glacial conditions.

Further south, periods of lake formation at Mudawwarra broadly correspond with these periods of increased humidity, however, while an age of ca. 152 ka for lake expansion corresponds well with records from the Levant, age estimates for an earlier humid period at ca. $170 \mathrm{ka}$ are less clear. Conversely, while Rosenberg et al. (2013) attribute a phase of lake formation in the southwestern Nefud to late-MIS 7, the age presented (maximum lake age of $177 \pm 13 \mathrm{ka}$ ) may also correspond with an early MIS 6 humid period, and an intensification of the African Monsoon at insolation maxima at ca. $175 \mathrm{ka}$. Thus, it is possible that African monsoon rainfall penetrated northwestern regions of the peninsula at two key intervals during MIS 6, although further data are required from regions such as southern Jordan and the Nefud in order to confirm this notion.

Within the Red Sea region a cooler climate, similar to that of the Mediterranean, was in place during MIS 6, with depressed sea levels exposing the 
Gulf of Suez and reducing the width across the Bab el Mandeb to $\sim 6 \mathrm{~km}$ (Siddall et al., 2004; Badawi, 2014). Marine cores from the southern Red Sea attest to insolationdriven climatic changes in the region, possibly driven by an enhanced winter (NE) monsoon, in which increased rainfall reduced deep-water ventilation (Badawi, 2014). Further evidence for an enhanced winter monsoon is found in planktic foraminifera records from the northwest Arabian Sea, where high abundances of species sensitive to winter circulation driven by NE monsoon convection (e.g. G. ruber and $G$. sacculifer) occur at ca. 175 and $147 \mathrm{ka}$ (Ishikawa and Oda, 2007). Accordingly, these ages correspond well with other marine evidence for monsoon enhancement during MIS 6 (e.g. Des Combes et al., 2005; Caley et al., 2011a), and with an Arabian Sea monsoon stack (Clemens and Prell, 2003).

It has been suggested that monsoon wind strength and rainfall are decoupled during glacial periods (Fleitmann et al., 2011), and that precipitation during glacialage monsoon/insolation maxima does not reach the Arabian interior. Indeed, speleothem data (e.g. Burns et al., 2001; Fleitmann et al., 2003) from Oman and Yemen indicate that the climate of southern and southeast Arabia remained arid throughout MIS 6. Despite this, however, there is evidence for lake formation at ca. $160 \mathrm{ka}$ in the Liwa region of the Rub' al-Khali (Wood et al., 2003), while palaeosol formation attributable to millennial-centennial scale periods of increased humidity is also reported from the Wahiba Sands, Oman ca. 160 ka (Preusser et al., 2002; Radies et al., 2004). More substantially, recent investigations report multiple phases of extensive alluvial fan activation in southeast Arabia, corresponding to periods of insolation maxima between MIS 6 and MIS 3 (Parton, 2013). Approximately half of the $\sim 42 \mathrm{~m}$ sequence at near Al Ain, UAE, was deposited during a late MIS 6 humid phase that occurred ca. 160-150 ka. Palaeoenvironmental evidence from the sequence indicates that during this time, an expansive freshwater corridor formed along the western flanks of the Hajar Mountains, comprising braided stream channels surrounded by a mixture of $\mathrm{C}_{3}$ and $\mathrm{C}_{4}$ grasslands. The absence of corresponding evidence in speleothem records from southern regions, may reflect poor archive preservation potential; speleothems require precipitation values in excess of 350 $\mathrm{mm} / \mathrm{yr}$ for growth (Vaks et al., 2006; Fleitmann et al., 2011) and as such, records may be fragmentary and inhibited by cave-specific features, particularly during periods of diminished rainfall (Fleitmann and Matter, 2009). Consequently, rainfall during MIS 
6 in southern and southeast Arabia appears to have been sufficient to activate alluvial fan and drainage networks, but not speleothem growth.

\section{FIGURE 3 HEREABOUTS}

\subsection{MIS 5 (ca. 130-75 ka)}

The global warm/cold climate oscillations of Marine Isotope Stage 5 are well represented as humid-arid shifts in palaeoclimate records from Arabia. With respect to the monsoon system, the onset of intensification during humid periods may have been particularly rapid (cf. Burns et al., 2003), with summer rainfall quickly transforming previously hyperarid desert regions into landscapes replete with freshwater lakes and rivers. While there may be some differences in the timing of humid phases between northern and southern regions of the peninsula, the occurrence of three distinct humid phases during MIS 5.5 (ca. 135-120 ka), MIS 5.3 (ca. 115-105 ka) and MIS 5.1 (ca. 85-75 ka) are now well documented, and coincide with insolation maxima. Of these, precipitation appears to have been of the greatest magnitude during MIS 5.5 (Vaks et al., 2006; Fleitmann et al., 2011).

In the Red Sea region, the intensification of the African monsoon led to freshwater influxes that lowered surface salinity and reduced deep-water formation (Badawi, 2014), and substantially altered the wind regime across the basin (Trommer et al., 2011). Similarly, Arabian Sea records reveal an abrupt decrease in dust influx and increased nutrient supply, and three distinct phases of upwelling caused by an intensified SW summer monsoon (e.g. Reichart et al., 1998; Des Combes et al., 2005; Clemens and Prell, 2003). Pollen and productivity data also show a pattern of increased continental wetness and an expansion of savannah grasslands during the last interglacial, along with a substantial rise in sea temperatures of up to $1.5^{\circ} \mathrm{C}$ warmer than any period since (e.g. Van Campo et al., 1982; Prell and Van Campo, 1986; Rostek et al., 1997; Emeis et al., 1995; Saraswat et al., 2005; Saher et al., 2009). Significantly, these data show that temperature differences between seasons may have been much larger during this period, with seasonally resolved proxy records using corals from the northern Red Sea (Felis et al., 2004) indicating a summer-winter water temperature range of $8.4^{\circ} \mathrm{C}$, due to cooler winters.

Speleothem records from Oman and Yemen (Burns et al., 1998; Burns et al., 2001; Fleitmann et al., 2003; 2011; Fleitmann \& Matter, 2009) also record significant 
increases in precipitation during MIS 5.5, 5.3 and 5.1. Growth and isotopic data $\left(\delta^{18} \mathrm{O}\right.$ and $\delta \mathrm{D}$ ) indicate that rainfall during these periods was 2-3 times greater than that of today, and derived from a southerly monsoonal source with no Mediterranean component (Fleitmann et al., 2011). Increased monsoon rainfall also led to the formation of large freshwater lakes in the southern and southeastern regions. At Saiwan in central Oman, a fluvial lake situated at the distal end of alluvial fans flanking the southern end of the Oman Mountains covered an area of $\sim 1400 \mathrm{~km}^{2}$ with a depth of up to $\sim 25 \mathrm{~m}$ (Rosenberg et al., 2012). OSL dating estimates place the age of lake formation somewhere between 132 and $104 \mathrm{ka}$, and although an exact age of formation is unclear, it is likely to coincide with humid phases associated with MIS 5.5 and 5.3. Other lake deposits are reported from the southwestern edge of the Rub' al-Khali, at the sites of Mundafan and Khujaymah (Rosenberg et al., 2011). At Mundafan, lake formation is recorded during MIS 5.3 (ca. $100 \mathrm{ka}$ ), at which time a large freshwater lake covering $\sim 300 \mathrm{~km}^{2}$ occupied the now hyper arid basin at the southern end of the Tuwayq escarpment. The presence of Charaphytes, Phragmites and Typha plants in the sediments indicate that the lake was fringed by reeds, whilst $\delta^{13}$ Corg values of phytoclasts indicate a predominance of $\mathrm{C}_{3}$ plants, reflecting a much cooler and wetter climate than that of the present day. To the east of Mundafan, and deeper into the Rub al Khali (Fig. 2), lake deposits at Khujaymah reveal the existence of a lake typified by fresh, open running water at ca. $125 \mathrm{ka}$ (MIS 5.5) (Rosenberg et al., 2011).

The widespread activation of freshwater drainage systems is also recorded by alluvial fan records from southeast Arabia. Located within the same vast bajada as the channels that once fed palaeolake Saiwan, fan records from the western Hajar at Al Sibetah (Parton, 2013) indicate three phases of fan aggradation between ca. 130 and $88 \mathrm{ka}$, typified by the formation of an extensive braidplain surrounded by $\mathrm{C}_{4}$ grasslands and a high proportion of woody taxa. The nature of the landscape within this vast braidplain is further evidenced at the archaeological site of Jebel Faya, where occupation at $\sim 125 \mathrm{ka}$ took place in an environment characterized by mixed $\mathrm{C}_{3} / \mathrm{C}_{4}$ grassland and tree cover (Bretzke et al., 2013). Drainage activation in the region is also recorded in a relict branch of Wadi Dhaid, situated $120 \mathrm{~km}$ north of Al Sibetah (Atkinson et al., 2013). Importantly, channel flow in the region was of the greatest magnitude during MIS 5.5, and at times freshwater corridors may have connected the Hajar Mountains with the Gulf coast (Farrant et al., 2012). Further south in southern 
Oman, the activation of ephemeral streams has been dated to ca. $106 \mathrm{ka}$ (MIS 5.3) and possibly associated with the presence of early human populations (Rose et al., 2011), although whether NW-flowing drainage channels connected the Dhofar plateau and lakes within the desert interior at this time, is presently unknown.

Dune records from southeastern regions of the peninsula also provide evidence for MIS 5 humidity. Soils intercalated within aeolian sand beds in the Wahiba, highlight breaks in dune formation during MIS 5, while fluvial gravels at the base of dunes correspond to an increase in rainfall during MIS 5.5 (Preusser et al., 2002). Similarly, evidence from the Liwa region of the Rub' al-Khali demonstrates that the preserved record of aeolian activity (Stokes and Bray, 2005) tends to correspond with humid phases, rather than arid ones. In broad terms, the preservation of dunes is facilitated during MIS 5 wet (stabilization) phases, and reduced during arid (increased mobility) phases. The concept of dunes as potential humidity indicators has been investigated in greater detail in a recent study across the UAE (Farrant et al., 2014, this issue).

To the north, lake formation is recorded at numerous sites along the southern and southwestern Nefud Desert during MIS 5 (Fig. 2). Rosenberg et al. (2013) report a series of interdunal, diatomaceous lake deposits featuring abundant plant remains that formed during MIS 5.5 and MIS 5.3. During these periods, diatom assemblages reveal shifts in lake water volume in response to precipitation changes, however, as with most Late Pleistocene lacustrine sequences from Arabia, the chronological resolution is too poor to establish the duration of humid periods in the region, or the length of time for which the lakes were potable for human populations. Recent studies have also identified palaeosol, calcrete and lacustrine deposits at the Jubbah Oasis in the Nefud, associated with increased humidity during MIS 5.5, 5.3 and 5.1., with archaeological material also dated to the latter stage (Petraglia et al., 2011; 2012; Groucutt et al., this issue b).

Approximately $300 \mathrm{~km}$ northwest of the Nefud, the magnitude of climatic amelioration in Arabia during MIS 5 is exemplified by the formation of palaeolake Mudawwarra, which reached peak water levels of $>40 \mathrm{~m}$ depth at ca. $130 \mathrm{ka}$ and covered an area of up to $2000 \mathrm{~km}^{2}$ (Petit-Maire et al., 2010). Situated within a series of large depressions and extending from southern Jordan into northern Saudi Arabia, aquatic faunal remains indicate the existence of a vast complex of perennial lakes between late-MIS 6 and MIS 5.1. While it is suggested that lake presence was 
continuous between these periods, given the spread of both ages and lakebed outcrops, it is also possible that lake formation occurred only during the well-defined MIS 5 humid phases (Fig. 3). Importantly, investigators suggest that the perennial nature and size of the lake complex implies a contribution of both monsoonal and Mediterranean rainfall. While it is uncertain whether Mediterranean rainfall reached as far south as Mudawwarra during MIS 5, much of the lake's extensive catchment is located in the southern Jordan highlands, where rainfall levels were likely higher (Jennings et al., this issue). Certainly, speleothem records from the central and northern Negev reveal a southward intensification of Mediterranean rainfall and significantly wetter climate during MIS 5.5, 5.3 and 5.1 (Bar-Matthews et al., 2003; Vaks et al., 2003; 2006; 2007; 2010), with precipitation in excess of $300 \mathrm{~mm}$ in the central Negev (Vaks et al., 2010). Speleothem growth in the southern Negev, however, was somewhat limited during MIS 5.5 (NHP-1), suggesting that the southward extension of rainfall from the Eastern Mediterranean did not extend beyond this region (Vaks et al., 2010). There is also some disagreement between speleothem records from across the Negev region, with records from the Dead Sea suggesting generally dry conditions during interglacials and a more humid climate during glacials (Torfstein et al., 2009; Sorin et al., 2010; Waldmann et al., 2010). Similarly, extreme dryness is also reported at the Azraq Oasis during MIS 5.5 (Cordova et al., 2013). These incongruities may suggest that orographic barriers such as the Negev Highlands may have played an important role in enhancing the rain shadow effect over the Dead Sea and Jordan Valley Margins (Vaks et al., 2003), while changes in the intensity and duration of rainfall may also have been important (Jennings et al., this issue). Waldmann et al. (2010) suggest that northward intrusions of moisture during interglacials from either a monsoonal source or through the development of Red Sea synoptic troughs, are superimposed on the Eastern Mediterranean climate signal. Indeed, MIS 5 humid periods in the Negev also correspond to sapropels S5-S3 and an intensification of the African Monsoon and as such, it is possible that the coeval intensification of southerly (monsoon/Red Sea) and westerly (Mediterranean) rainfall during MIS 5 facilitated demographic movements between these regions (Vaks et al., 2013). It should be noted, however, that it remains unclear as to whether a spatial overlap of Mediterranean and tropical rainfall-bearing systems existed during MIS 5.5. In particular, the strong N-S precipitation gradient 
demonstrated throughout the Negev speleothem records (Vaks et al., 2010; 2013) would seem to suggest that monsoon rainfall did not reach the southern Negev.

While there is clearly a large body of evidence from across Arabia that attests to three distinct humid periods during MIS 5, less is known about the intervening stadials MIS 5.4 and MIS 5.2. It appears, however, that insufficient rainfall penetrated the southern/southeastern Arabian margin to initiate speleothem growth during these times (e.g. Burns et al., 1998; Fleitmann et al., 2003; 2011). Similarly, records from the Arabian Sea indicate reductions in productivity (e.g. Reichart et al., 1998; Clemens and Prell, 2003), while lake archives suggest breaks in lacustrine deposition between MIS 5 humid phases, likely attributable to increased aridity during stadial conditions (Rosenberg et al., 2011; 2012).

\subsection{MIS 4 (ca. 75-60 ka)}

MIS 4 was marked by a substantial shift towards increased aridity throughout much of Arabia, following the onset of global glacial conditions. Evidence from the Indian Ocean and Arabian Sea (e.g. Pattan et al., 1999; Song et al., 2000) and in particular, across peninsular India (e.g. Shane et al., 1995; Williams et al., 2006) indicates that a major isochronous change in vegetation from forest to grassland occurred during the early last glacial. In comparison to other Arabian palaeoclimatic and palaeoenvironmental records from MIS 7 through to MIS 1, MIS 4 suffers from perhaps the most significant paucity of terrestrial data. This is due in large part, to the highly destructive, erosional forces at work during this apparently arid period. Only minor evidence of dune accumulation is recorded within the Liwa region during MIS 4 (Stokes \& Bray; 2005), with increased dune mobility under hyper-arid conditions resulting in poor preservation (Farrant et al., this issue). In the Wahiba, only minor aeolian deposition occurred during MIS 4 (Preusser, 2009), whilst limited aeolian sandstone outcrops of the Hawiyah Unit (Radies et al., 2004) are also indicative of the localised reworking of the sand sea, as opposed to an influx of new material.

Speleothem records from Oman (e.g. Burns et al., 1998; Fleitmann et al., 2003) record no growth during this time, reinforcing the notion of a suppressed ITCZ and associated monsoon belt.

Marine records yield notably more information. $\mathrm{Mg} / \mathrm{Ca}$ and $\delta^{18} \mathrm{O}$ values of $G$. sacculifer from the Eastern Arabian Sea (Banakar et al., 2010) indicate that SST were substantially colder during MIS 4, while productivity proxies, also recorded from an 
Arabian Sea core (Pattan et al., 2009) suggest that MIS 4 initiated near-oxic conditions with low productivity, increased terrigenous input and increased pteropod preservation (Klöcker et al., 2006). A record of dust supply from the northern Arabian Sea (Reichart et al., 1997) also reveals a particularly arid climate during MIS 4 from ca. $74 \mathrm{ka}$, with significantly lower sea surface temperatures (Saraswat et al., 2005). In the Negev, however, generally wet and cool conditions prevailed. Speleothem records indicate that continuous deposition occurred between ca. 76-13 ka (e.g. Bar-Matthews et al., 2000; Vaks et al., 2006), and it was during MIS 4 that the Dead Sea precursor, Lake Lisan, experienced high stands (e.g. Machlus et al., 2000; Bartov et al., 2002; Lisker et al., 2010). Within the Azraq Oasis, lacustrine conditions commenced following the transition from MIS 5.1-MIS 4 (Cordova et al., 2013), likely as a result of groundwater recharge, however, there were notable fluctuations between wetter and drier conditions. As such, some degree of continental humidity persisted within certain regions of Jordan and Israel, possibly as a result of decreased evaporation under cooler conditions.

\subsection{MIS 3 (ca. $60-30 \mathrm{ka})$}

Marine records from the Arabian Sea and Indian Ocean indicate that MIS 3 was a particularly complex and unstable climatic period, with intense millennial-scale temperature oscillations that exceeded $6^{\circ} \mathrm{C}$ (Siddall et al., 2010); a difference of more than half of the global glacial-interglacial temperature change (Sakai and Peltier, 1999). Mid-Late MIS 3 (ca. 40-30 ka) lake sequences have been reported at various sites in Jordan (e.g. Schuldenrein and Clark, 1994; Moumani et al., 2003; Cordova et al., 2013), and precipitation increases during insolation maxima at ca. $61 \mathrm{ka}$ and $33 \mathrm{ka}$ have been recorded in the northern Negev (Vaks et al., 2006). Despite this, no speleothem growth was recorded in the central and southern Negev during MIS 3 (Vaks et al., 2010), suggesting that once again, southward moisture transport was limited to the northern Negev. Reduced African Monsoon convection prevented sapropel formation in the Mediterranean, while no lake formation was recorded at Mudawwarra in southern Jordan.

Evidence for increased humidity elsewhere in Arabia has, until recently, been controversial. This is largely due to an absence of evidence for increased wetness in key archives such as large freshwater lake records and speleothems, and also because the dating limit of radiocarbon (upon which many early MIS 3 dates were based), falls 
within MIS 3. Early research at sites in the Rub' al-Khali and Mundafan depression (McClure, 1976; Wood and Imes, 1995) and the Nefud Desert (Garrard et al., 1981; Schultz and Whitney, 1986), reported a prolonged wet period between ca. 35 and 20 ka. More recently, redating of lake sediments from these regions has shown that lake formation at the sites actually occurred during MIS 5, with previous younger ages most likely the result of contamination by younger material (Rosenberg et al., 2011; 2012). This has led some researchers to conclude that climatic conditions within the interior of Arabia remained arid throughout MIS 3 (e.g. Fleitmann et al., 2011; Rosenberg et al., 2011), with the implication that demographic movements through the interior were impossible at this time.

However, recent records from central and southern Arabia indicate that a potentially important humid period may have occurred near the onset of MIS 3, following an incursion of rainfall corresponding to an insolation maximum between ca. 60-50 ka. In the UAE and Oman, the reactivation of rivers occurred at ca. $55 \mathrm{ka}$ (Fig. 2), following the re-establishment of alluvial fan processes within the vast bajada that had been previously active during MIS 5 (Krbetschek, 2008; Blechschmidt et al., 2009; Farrant et al., 2012; Parton, 2013; Parton et al., 2013; Hoffmann et al., 2014, this issue). This was accompanied by the development of grasslands and lake formation in distal-fan regions (Parton et al., 2013). While the duration of increased humidity reflected in these records remains uncertain (Hoffmann et al., 2014), the incursion of rainfall at this time also corresponds with various marine proxies (denitrification, foraminifera assemblages and sea surface temperatures); all of which reflect a strengthening of the monsoon and increased productivity at ca. 55 ka (e.g. Schulz et al., 1998; Altabet et al., 2002; Clemens and Prell, 2003; Higginson et al., 2004; Des Combes et al., 2005; Ivanochko, 2005; Govil \& Naidu, 2010; Caley et al., 2011a). Although this 'debated pluvial' (cf. Parker, 2009) has not been identified in speleothems from the Arabian mainland (e.g. Fleitmann et al., 2011), an increase in monsoon precipitation has been recorded in speleothems on the island of Socotra in the Indian Ocean (Burns et al., 2003). These indicate that the onset of early MIS 3 humidity was particularly intense and abrupt, occurring within as little as $\sim 25$ years.

While an early MIS 3 insolation peak corresponds with an intensified African Monsoon in marine records (Caley et al., 2011a), there is little evidence to suggest that rainfall derived from this system had any significant impact on the interior 
landscape of Saharan Africa at this time. Some MIS 3 humidity is recorded in northern and eastern regions of the Sahara; however, this is somewhat later at ca. 40 ka (Drake et al., 2013). Additionally, it is unclear whether increased monsoon rainfall extended into the Red Sea region during MIS 3 (Almogi-Labin et al., 1998). Nonetheless, there is some evidence for the activation of fluvial channels in central Saudi Arabia at ca. $54 \mathrm{ka}$ (McLaren et al., 2008), which is in keeping with records from southeast Arabia, and possibly indicative of the incursion of moisture from a southern/southwestern source. At the onset of MIS 3 there is a notable decline in dust transport into the Arabian Sea (Clemens and Prell, 2003), while critically for potential dispersals by a southern route, sea levels also remained particularly low. As such, the exposure of large areas of the continental shelf and reduction of the width across the Bab el Mandeb to just $6 \mathrm{~km}$ (Rohling et al., 2014), appear to have been coeval with landscape stabilisation, increased rainfall and enhanced marine productivity. This combination of improved climate and resource availability would potentially have facilitated population expansions into Arabia through a southern route, sometime between ca. 60 and $50 \mathrm{ka} \mathrm{BP}$.

\section{FIGURE 4 HEREABOUTS}

\subsection{Synthesis: Arabian palaeoclimate and human dispersals \\ 4.1 Glacial-Interglacial Climates}

Evidence from marine and terrestrial archives indicates that over the past ca. 245 thousand years, humid phases recorded in and around the Arabian Peninsula have corresponded with insolation maxima, with a strong emphasis on the precessional component. Rainfall, derived predominantly from the African and Indian Ocean monsoon systems, led to the periodic expansion of rivers, lakes and grassland environments across previously arid-hyperarid regions, thus expanding biogeographical zones and facilitating faunal expansions. Importantly, the occurrence of increased rainfall during both glacial and interglacial periods in Arabia refutes the notion that demographic connectivity and potential dispersals would have been exclusively limited to eccentricity-modulated interglacials. This is in strong contrast to the situation at high latitudes in NW Europe, where a long tradition of Quaternary 
research has been underpinned by human absence or significant range contraction during Pleistocene cold stages.

It is important to consider, however, that humidity in Arabia was not equal or uniform during insolation maxima, with full interglacial conditions being theoretically more conducive to inter-regional and trans-continental demographic connectivity than glacial-age wet phases. The palaeoclimatic record of Arabia indicates that increased rainfall and the subsequent activation of drainage systems would have been most pronounced during mid-high latitude interglacials, with a threefold increase in precipitation in many regions (Fleitmann et al., 2011). Indeed, a strengthened interglacial African monsoon also led to the development of confluent fluvial systems across the Sahara (Drake et al., 2011; Scerri et al., 2014) and the subsequent formation of sapropels in the Mediterranean; the timing of which closely correspond to humid periods recorded in Arabian marine and terrestrial sequences. Lake records from both southern and northern desert regions attest to the widespread nature of interglacial humidity in Arabia, with tropical moisture possibly reaching as far north as Mudawwarra in southern Jordan. Eastern Mediterranean cyclonic systems were also intensified during interglacials (e.g. Petit-Maire et al., 2002; Vaks et al., 2007; $2010 ; 2013)$, and as such there is a temporal correspondence between insolationdriven humidity across Arabia, the Negev and the Levant over the past ca. 245 thousand years (Fig. 3). While the exact length of pluvials remains unknown, humid episodes were likely typified by widespread drainage activation throughout these regions, giving rise to greater water availability and increased vegetational cover (Weinstein-Evron, 1987; Vaks et al., 2007). We hypothesise therefore, that during interglacials favourable environmental conditions connected Arabia to surrounding regions such as the Levant and Sinai Peninsula, facilitating demographic connectivity between these regions.

At present, the Arabian palaeoclimatic record does not indicate that similar peninsula-wide humidity was in place during glacial-age wet phases. While the emerging climatic picture of Arabia indicates that the inland convection of monsoon rainfall was not inhibited during glacials, it is likely that a more complex spatial distribution of rainfall was in place. Increased mid-high latitude glacial boundary conditions restricted precipitation to $<350 \mathrm{~mm}$ per year, preventing speleothem growth and substantial lake formation. In central and southern regions, the only palaeoenvironmental records that indicate increased rainfall are alluvial fan and 
fluvial archives, which appear to be more sensitive to climatic fluctuations. Perhaps significantly, palaeomonsoon records from the Arabian Sea indicate that periods of increased rainfall during glacials may have been the result of an intensified NE-winter monsoon (e.g. Mason et al., 2006; Badawi et al., 2014), potentially driven by southern hemispheric temperature changes. Consequently, while Arabia may not have presented an 'arid barrier' to human populations during glacials, demographic mobility during these times would likely have been limited to those regions of the peninsula in which drainage systems were active. Seasonal fluctuations in freshwater availability would, therefore, have been significant controls upon demographic exchange and survival, and an enhanced mobility/ability to react to these fluctuations may be a characteristic of contemporaneous populations (sensu Finlayson 2013, 2014).

In the northwest, however, the formation of a large lake complex at Mudawwarra during MIS 6, when global ice build-up was high, presents an interesting question as to the source of moisture in northern regions at this time. Accepting the validity of the ages of lake formation at Mudawwarra, it is unlikely that such a substantial latitudinal shift of the ITCZ would have occurred to allow Indian Ocean Monsoon rainfall to reach so far north. Similarly, a lack of contemporaneous evidence for increased rainfall in the southern Negev would seem to suggest that the source was not winter rainfall from the Eastern Mediterranean, although the full southward extension of drainage from the Negev is not yet established and may prove to be critical in determining the connectivity between these regions. It is possible that rainfall in the region was the result of an eastward extension of the African Monsoon, with a potential contribution of synoptic conditions associated with the Red Sea troughs (Waldmann et al., 2010), however, the absence of sapropel formation between ca. 170 and $130 \mathrm{ka}$ is incongruous with an intensified African monsoon. Clearly, further investigation from the northernmost regions of Arabia is required to elucidate the potential for demographic movements from the north and west during global glacial periods.

\section{2. 'Windows' for Dispersal}

In the light of the steadily expanding body of evidence for humid phases in Arabia over the past ca. $245 \mathrm{ka}$, a critical question concerns the extent to which demographic connectivity between northern and southern regions was enhanced or inhibited during 
the Middle-Late Pleistocene. With respect to the monsoon system, climate changes at the onset and termination of humid phases were rapid, opening and closing potential routes into and through the peninsula over short (likely multi-decadal) timescales. Consequently, the potential for populations to expand into and throughout the region may have been dramatically altered within just one or two generations. In analysing a range of palaeoclimatic archives, it may be possible to speculate as to potential zones of demographic connectivity based on humidity indicators.

A longstanding paradigm concerning potential routes out of Africa has primarily been a northern route through the Sinai Peninsula. A number of researchers have previously suggested that increased humidity throughout the Saharo-Arabian Desert belt may have facilitated faunal migrations out of Africa and through the Levant and Negev (e.g. Vaks et al., 2007; 2010; Waldmann et al., 2010; Frumkin et al., 2011), and possibly into Arabia (e.g. Rose and Petraglia, 2009; Petraglia, 2011; Cordova et al., 2013), although few comparisons between the climates of these regions have been made. Arguably, the most likely period in which coeval precipitation increases between these regions would have favoured biogeographic connectivity and facilitated human dispersal was the last interglacial; the earliest period for which fossil evidence has confirmed the presence of human populations outside Africa (see Grun et al., 2005; Shea 2008; Groucutt et al., 2014, this issue a, for further discussion). While the absence of fossil evidence for Homo sapiens in the region between ca. 80 and $40 \mathrm{ka}$ has engendered the notion of this being a 'failed expansion', it is important to consider the nature of the environment into which early human populations would have expanded. Having crossed the Sinai-Negev landbridge at the onset of MIS 5, coeval precipitation increases between the Negev and Nefud would have allowed these populations to then expand further into the Arabian interior. MIS 5.5 is the only period over the past ca. 245 thousand years in which increased rainfall extended between the eastern Mediterranean region and southern Negev at the same time that large freshwater lakes formed in southern Jordan at Mudawwarra, and in the western and southern Nefud (Fig. 4).

A key issue, therefore, is whether there was ever sufficient spatial-temporal overlap (in terms of increased humidity and biomass) between the Negev and Nefud deserts, or whether a sharp north-south precipitation gradient allowed an arid barrier to persist between these regions. Modelled palaeoprecipitation for Arabia during MIS 5.5 (Fig. 4) suggests that even at its most humid, an arid zone persisted at the 
northernmost extent of the peninsula. And yet, the presence of a large freshwater lake at Mudawwarra during this period would seem to refute this notion, indicating that precipitation in the region was sufficient to form a large perennial lake. It is possible that lake formation was aided by a combination of both winter (Mediterranean) and summer (monsoonal) rainfall (Petit-Maire, 2010), combined with a substantial catchment area and associated drainage network extending to the north. Furthermore, while a decrease in speleothem thickness between the north and southern Negev would appear to limit the southward extent of Mediterranean rainfall to the southern Negev, it is possible that the simultaneous intensification of both Mediterranean cyclones and the monsoon during MIS 5.5 may have allowed rainfall to penetrate into the northern reaches of Arabia from both the north and the south (Vaks et al., 2010).

Unfortunately at present, we lack sufficient data to confirm connectivity between the Negev and Nefud, which lie $\sim 600 \mathrm{~km}$ and $\sim 3^{\circ}$ of latitude apart. However, we suggest that coeval precipitation increases in these regions during the last interglacial, possibly aided by the development of Red Sea convective systems during the autumn and spring, may have led to a reduction in the arid belts of NW Arabia, facilitating biogeographic exchange and demographic expansions into the Arabian interior. Once in the Nefud, populations would have been able to exploit a landscape littered with interdunal freshwater bodies, dispersed over $\sim 300 \mathrm{~km}$ between western and central desert regions (Petraglia et al., 2011; Rosenberg et al., 2013; Breeze et al., 2014, this issue; Scerri et al., 2014, this issue). Although the amount of annual rainfall required to form such water bodies is not well understood; factors such as accommodation space, basin topography, groundwater recharge and fluvial input make any generalisations impossible, it is reasonable to expect that lake formation would have been accompanied by the expansion of regional vegetation. Indeed, recent palaeoprecipitation models indicate that during the last interglacial, the East African monsoon brought rain to the interior of Arabia during the winter months, as well as the summer (Jennings et al., 2014, this issue). This would have dramatically increased the amount of annual rainfall received in northern regions, further extending the range over which human and faunal populations could seasonally expand. Although presently mostly undated, the large number of Middle Palaeolithic sites, generally associated with relict lake deposits and scattered across the Nefud, attest to the close connection between expanding populations and lake development (Breeze et al., 2014, this issue; cf. Scerri et al., 2014, this issue). 
For a southern dispersal route, human populations were required to cross the Red Sea, since there is no evidence to suggest that a land bridge ever connected Africa and Arabia after the Miocene. Following the melting of major ice sheets during the last interglacial, sea levels rose by $\sim 1.6 \mathrm{~m}$ per century, reaching up to $9 \mathrm{~m}$ above present levels by ca. $123 \mathrm{ka}$ (Rohling et al., 2008). However, this considerable sealevel rise lagged behind the onset of humid conditions in southern regions of Arabia, which began by ca. $130 \mathrm{ka}$, and possibly as early as $135 \mathrm{ka}$ (Fleitmann et al., 2003). In shallow regions such as the southern Red Sea, such a lag may have been critical in facilitating dispersal (Armitage et al., 2011), with human populations exploiting a reduction in the gap across the Bab el Mandeb to $\sim 6 \mathrm{~km}$ (Rohling et al., 2013) at a time of widespread climatic amelioration. Palaeoenvironmental evidence from southern and southeastern regions indicate that populations would have been expanding into a landscape of freshwater lakes, streams and rivers, which formed following an intensification and northward shift of monsoon rainfall. The north and eastwards flow of drainage from regions such as the Dhofar Plateau in Southern Oman, the Yemen Highlands and the southern Asir into the previously hyperarid Rub' al-Khali, led to extensive freshwater lake formation along the southern periphery of the desert (e.g. Rosenberg et al., 2011; Matter et al., 2014, this issue). To the east, the widespread activation of drainage systems within a vast bajada along the western and southern flanks of the Oman Mountains, would have further facilitated population expansions into the continental interior and towards the Gulf and Straits of Hormuz (Atkinson et al., 2012; Parton, 2013). Situated at the northern end of the bajada, Middle Palaeolithic assemblages are reported from the rock shelter site of Jebel Faya dated from ca. $130 \mathrm{ka}$, demonstrating the presence of early communities within this expansive freshwater corridor (Armitage et al., 2011).

At present, it is unclear whether environmental conditions deteriorated sufficiently during the proceeding MIS 5.4 and MIS 5.2 stadials to prevent occupation of Arabia, or whether some degree of continuity was possible between the three MIS 5 humid periods. It is possible that populations were forced to contract into refugial zones such as the Azraq Oasis, in which the persistence of marshlands during climatic downturns would have allowed populations to persist at an important crossroads between the Levant and Arabia (Cordova et al., 2013). Certainly, subsequent environmental conditions during MIS 5.3 and 5.1 were conducive to the occupation of interior desert regions once again, following the reactivation of rivers and lakes 
previously active during MIS 5.5. Additionally, the presence of lakes in the southern Nefud and Mudawwarra during these periods suggest the possible reestablishment of biogeographic connectivity along a northern route into/out of Arabia and again, there is some temporal overlap with evidence for humidity in the Negev.

A number of archaeological sites indicate the burial of Middle Palaeolithic artefacts during humid periods associated with insolation maxima. These include the site of Aybut Al Auwal in Dhofar which has a minimum age of ca. 106 ka (Rose et al., 2011), assemblages at Mundafan where lake sediments have been dated to MIS 5.3 and 5.1 (Crassard et al., 2013; Rosenberg et al., 2013), and several sites in the southern Nefud (Petraglia et al., 2012; Groucutt et al., this volume b; Scerri et al., this volume). In most cases the burial of the archaeological material seems to have occurred in mid-to-late MIS 5.

Of particular relevance to the debate concerning human dispersals are the climatic conditions in Arabia during the last glacial period, in particular, the proposed late dispersal of modern humans in early MIS 3 (Mellars, 2006; Mellars et al., 2013). Previously, environmental conditions in Arabia at this time have been considered too arid to support human populations, and while this is not viewed as a causal mechanism for coastal expansion, it has perhaps discouraged consideration of an interior route through the peninsula at this time. A number of records now indicate a period of increased monsoon rainfall sometime between ca. 60 and $50 \mathrm{ka}$, which led to drainage activation in southern and southeastern regions, coincident with increased productivity in the Arabian Sea (e.g. Clemens and Prell, 2003; Des Combes et al., 2005; Farrant et al., 2012; Parton et al., 2013). Critically, this period of monsoon intensification came at a time of depressed sea levels where a $17 \mathrm{~m}$ deep and $6 \mathrm{~km}$ wide channel persisted at Hanish Sill in the Red Sea (Siddall et al., 2004). Low dust levels at this time reflect more favourable conditions for habitation in low latitude regions, with higher soil cohesion, reduced wind strength and improved food resources along coastal regions. Rohling et al. (2014) identify a critical window of $65+5 /-8$ ka for the dispersal of population out of Africa via a southern route across the Bab al Mandeb, which within error, broadly corresponds with the emerging Arabian palaeoclimatic record.

This is not to say, however, that an interior route would have been preferable; an exposed coastal shelf combined with increased productivity and an enhanced monsoon, would have likely presented an important biogeographic zone for 
expanding populations. Rather, the activation of drainage systems by summer monsoon rainfall along a southern route (Parton et al., 2013), may have presented suitable seasonal corridors into the interior, particularly in places where a lack of exposed continental shelf may have precluded coastal movements, such as regions of southern Oman. Middle Palaeolithic assemblages distributed along Wadi Surdud in southern Yemen and dated to ca. $55 \mathrm{ka}$, may support this notion (Delagnes et al., 2012). The technological characteristics of the Wadi Surdud assemblages, however, are unlike those from Africa and elsewhere in Arabia at the time, and may be more indicative of connections to MIS 4/3 populations in the Levant. Similarly, the MIS 3 occupation of Jebel Faya led to the production of lithics unlike those found in Africa at the same time (Armitage et al., 2011). These findings may reflect the autochthonous development of extant populations in southern Arabia, and/or connections with areas such as Iran rather than Africa, highlighting the importance of further archaeological and palaeoenvironmental information from this critical time period which, until recently, was considered part of an extended arid phase.

Finally, it is pertinent to consider the potential duration and stability of humid periods in Arabia. Unfortunately at present, limited information is available from terrestrial archives, however, using the Holocene as a more recent analogue, it might be reasonable to expect that humid periods were punctuated by substantial arid phases. Records from southeast Arabia (e.g. Parker et al., 2004; 2006; Preston et al., 2011; 2014, this issue) have shown that abrupt returns to aridity occurred at ca. 8.2, 5.8 and $4.2 \mathrm{ka}$, triggered by rapid climatic changes in the North Atlantic corresponding with Bond Events. These relatively brief (multi-centennial-scale) arid periods in Arabia were sufficient to significantly disrupt Neolithic occupation of the region (Preston et al., 2011). Despite the present paucity of data, it is likely that similar climatic perturbations occurred during previous humid phases and that such abrupt climatic downturns would have greatly impacted upon earlier populations. Similarly, the predominance of a monsoonal climate regime throughout much of the peninsula during humid periods, would have amplified climatic seasonality and by extension, landscape change. As a result, the mobility of early populations would likely have been driven by seasonal changes in the availability of freshwater. This may have led to the movement of populations into coastal and mountainous regions during the dry season, where food and freshwater resources persisted, and into the desert interior during the wet season, following the re-expansion of wetlands and 
lakes. It is also likely that there could be some variability in precisely how tightly early populations were tied to such changing water resources over time (Breeze et al., this issue). Therefore, notions of climatic 'windows' of opportunity for demographic expansion should not be determinant but remain loose concepts in which to frame the potential for expansion, as even a few hundred years of enhanced seasonal freshwater availability may have allowed mobile hunter-gatherer communities to disperse several thousand kilometres.

\subsection{Conclusions}

Previous conceptions of demographic change in Arabia have been constrained by an incomplete palaeoclimatic record. A paucity of records and apparent disparities between some archives, has led to a simplified dichotomous notion of 'wet' interglacials and 'dry' glacials, in which environmental changes in Arabia are placed within a mid-high latitude framework of eccentricity-paced glaciations. This has also been shaped by a strong focus on lake and speleothem archives which, while important, do not reflect the full range of rainfall in key regions of the peninsula, particularly during 'weaker' glacial humid periods. Additionally, the precise nature of the duration and stability of key periods such as the last interglacial is not yet known. Critical to resolving these issues is the need for both a wide range of palaeoenvironmental archives that are sensitive to larger scales of humidity changes, and long terrestrial environmental sequences from which high resolution (i.e. seasonal) palaeoenvironmental records can be constructed.

Despite these on going issues, however, this synthesis of palaeoclimatic records from across and around the Arabian Peninsula has allowed us to broadly characterise the spatial distribution and periodicity of climate change across the Arabian Peninsula over the past ca. 245 thousand years. In particular, we highlight the close correspondence between humid periods within the Arabian interior and precessionally-paced insolation maxima. During these periods, the incursion of monsoon rainfall into the Arabian interior would have facilitated the movements of human populations through improved freshwater resources. Increased continental rainfall and environmental amelioration occurred during both glacial and interglacial periods, although the degree of humidity has been strongly determined by external and internal global climate parameters. During MIS 5, we hypothesise that coeval increases in humidity between the eastern Mediterranean and northern Arabia created 
favourable conditions for demographic transfer between Africa and northern Arabia. The formation of freshwater lakes across the Nefud desert during this time would have also permitted further southward expansions into the Arabian interior. In southern regions, a lag between increased summer monsoon rainfall and rising sea levels may also have allowed human populations to take advantage of a narrow Bab el Mandeb and expand into Arabia via a southern route during MIS 5.5 (at ca. $130 \mathrm{ka}$ ), Further periods of increased Peninsula-wide humidity are also observed during MIS 5.3 (ca. 115-105 ka) and during MIS 5.1 (ca. 85-75 ka), which coincide with dated archaeological sites indicative of further range expansions into the interior.

While palaeoclimatic records indicate that rainfall was greatest during midhigh latitude interglacials, a growing number of archives demonstrate that strong monsoons also occurred in glacial times during insolation maxima. Incursions of rainfall during these periods were insufficient for speleothem growth in southern and southeastern regions, however, freshwater availability nonetheless increased as a result of an intensified and northwardly displaced monsoon system. In particular, we identify two potentially key periods of monsoon maxima at ca. $155 \mathrm{ka}$ and 60-50 ka, which occurred at times of low sea levels and increased coastal productivity. Importantly, increased freshwater resources within the Arabian interior and increased productivity in coastal zones during early MIS 3, indicate that favourable environmental conditions existed along both coastal and interior routes at a potentially critical time for human population movements out of Africa.

\section{Acknowledgements}

Our research has been funded by the European Research Council (ERC Advanced Grant no. 295719 to MDP). We thank HRH Prince Sultan bin Salman, Prof. Ali Ghabban, Abdulaziz Al Omari and the staff of the SCTA for their support, Dr. Abdullah Alsharekh, of King Saud University, and two anonymous reviewers for their constructive feedback.

\section{References}

Almazroui, M., 2011. Sensitivity of a regional climate model on the simulation of high intensity rainfall events over the Arabian Peninsula and around Jeddah (Saudi Arabia). Theoretical and Applied Climatology 104(1-2), 261-276. 
Altabet, M., Higginson, M., Murray, D., 2002. The effect of millennial-scale changes in Arabian Sea denitrification on atmospheric $\mathrm{CO}_{2}$. Nature 415, 159-162.

Armitage, S.J., Jasim, S.A., Marks, A.E., Parker, A.G., Usik, V.I., Uerpmann, H-P., 2011. The southern route "out of Africa": evidence for an early expansion of modern humans into Arabia. Science 331 (6016), 453-456.

Arz, H.W., Lamy, F., Patzold, J., Muller, P.J., and Prins, M., 2003, Mediterranean moisture source for an early-Holocene humid period in the northern Red Sea. Science $300,118-121$.

Atkinson, O.A.C., Thomas, D.S.G., Parker, A.G., Goudie, A.S., 2013. Late Quaternary humidity and aridity dynamics in the northeast Rub' al-Khali, United Arab Emirates: implications for early human dispersal and occupation of eastern Arabia. Quaternary International 300, 292-301.

Ayalon, A., Bar-Matthews, M. \& Kaufman, A., 2002. Climatic conditions during marine oxygen isotope stage 6 in the eastern Mediterranean region from the isotopic composition of speleothems of Soreq Cave, Israel. Geology 30(4), 303-306.

Badawi, A., Schmiedl, G. \& Hemleben, C., 2005. Impact of late Quaternary environmental changes on deep-sea benthic foraminiferal faunas of the Red Sea. Marine Micropaleontology 58, 13-30

Badawi, A., 2014. Late quaternary glacial/interglacial cyclicity models of the Red Sea. Environmental Earth Sciences 1866-6280, 1-17. DOI 10.1007/s12665-014-34468

Banakar, V., Mahesh, B.S., Burr, G., Chodankar, A.R., 2010. Climatology of the Eastern Arabian Sea during the last glacial cycle reconstructed from paired measurement of foraminiferal $\mathrm{d} 18 \mathrm{O}$ and $\mathrm{Mg} / \mathrm{Ca}$. Quaternary Research 73, 535-540

Bar-Matthews, M., Ayalon, A., and Kaufman, A., 2000, Timing and hydrological conditions of sapropel events in the Eastern Mediterranean, as evident from speleothems, Soreq Cave, Israel. Chemical Geology 169, 145-156.

Bar-Matthews, M., Ayalon, A., Gilmour, M., Matthews, A., Hawkesworth, C.J., 2003. Sea- land oxygen isotope relationships from planktonic foraminifera and speleothems in the eastern Mediterranean region and their implication for paleorainfall during interglacial intervals. Geochimica et Cosmochimica Acta 67, 3181-3199.

Bard, E., Delaygue, G., Rostek, F., Antonioli, F., Silenzi, S., Schrag, D.P., 2002. Hydrological conditions over the western Mediterranean basin during the deposition of the cold Sapropel 6 (ca. 175 kyr BP). Earth and Planetary Science Letters 202, 481494.

Barth, H.-J., Steinkohl, F., 2004. Origin of winter precipitation in the central coastal lowlands of Saudi Arabia. Journal of Arid Environments 57(1), 101-115. 
Bartov Y., Stein M., Enzel Y., Agnon A., Reches Z., 2002. Lake levels and sequence stratigraphy of Lake Lisan, the late Pleistocene precursor of the Dead Sea. Quaternary Research 57, 9-21.

Blechschmidt, I., Matter, A., Preusser, F., Rieke-Zapp, D., 2009. Monsoon triggered formation of Quaternary alluvial megafans in the interior of Oman. Geomorphology $110,128-137$.

Boos, W.R. \& Emanuel, K.A., 2009. Annual intensification of the Somali jet in a quasi-equilibrium framework: Observational composites. Quarterly Journal of the Royal Meteorological Society, 135(639), 319-335.

Breeze, P.S., Drake, N.A., Groucutt, H.S., Parton, A., Jennings, R.G., Clark-Balzan, L., Shipton, C., White, T.S., Scerri, E., Stimpson, C., Crassard, R., Hilbert, Y., Petraglia, M.D., Alsharekh, A., Al-Omari, A., 2014. Remote sensing and GIS techniques for reconstructing Arabian palaeohydrology and identifying and characterising archaeological sites. Quaternary International, this issue, in submission

Bretzke, K., Armitage, S.J., Parker, A.G., Walkington, H., Uerpmann, H-P., 2013. The environmental context of Paleolithic settlement at Jebel Faya, Emirate Sharjah, UAE. Quaternary International 300, 83-93.

Burns, S., Matter, A., Frank, N., Mangini, A., 1998. Speleothem-based paleoclimate record from northern Oman. Geology 26 (6), 499-502.

Burns, S.J., Fleitmann, D., Matter, A., Neff, U., Mangini, A., 2001. Speleothem evidence from Oman for continental pluvial events during interglacial periods. Geology 29, 623- 626.

Burns, S.J., Fleitmann, D., Matter, A., Kramers, J., Al-Subbary, A. A., 2003. Indian Ocean Climate and an Absolute Chronology over Dansgaard/Oeschger Events 9 to 13. Science 301(5638), 1365-1367.

Caley, T., Malaize, B., Zaragossi, S., Rossignol, L., Bourget, J., Eynaud, F., Martinez, P., Giraudeau, J., Charlier, K., Ellouz-Zimmermann, N., 2011a. New Arabian Sea records help decipher orbital timing of Indo-Asian monsoon. Earth and Planetary Science Letters, 308(3-4), 433-444.

Caley, T., Malaize', B., Revel, M., Ducassou, E., Wainer, K., Ibrahim, M., Shoeaib, D., Mi- geon, M., Marieu, V, 2011b. Orbital timing of the Indian, East Asian and African boreal monsoons and the concept of a "global monsoon", Quaternary Science Reviews 30, 3705-3715.

Caley, T., Zaragosi, S., Bourget, J., Martinez, P., Malaize, B., Eynaud, F., Rossignol, L., Garlan, T., Ellouz-Zimmermann, N., 2013. Southern Hemisphere imprint for Indo-Asian summer monsoons during the last glacial period as revealed by Arabian Sea productivity records. Biogeosciences Discussions 10, 9315-9343 
Clemens, S., Prell, W.L., 1990. Late Pleistocene variability of Arabian Sea summer monsoon winds and continental aridity: Eolian records from the lithogenic component of deep-sea sediments. Paleoceanography 5, 109-145.

Clemens, S., Prell, W., Murray, D., Shimmield, G., Weedon, G., 1991. Forcing mechanisms of the Indian Ocean monsoon. Nature 353, 720-725.

Clemens, S., Prell, W.L., 2003. A 350,000 year summer-monsoon multi-proxy stack from the Owen Ridge, Northern Arabian Sea. Marine Geology 201, 35-51.

Clift, P.D., Plumb, R.A., 2008. The Asian Monsoon: Causes, History and Effects. Cambridge University Press, pp. 270.

Cordova, C.E., Nowell, A., Bisson, M., Ames, C.J.H., Pokines, J., Chang, M., alNahar, M., 2013. Interglacial and glacial desert refugia and the Middle Paleolithic of the Azraq Oasis, Jordan. Quaternary International 300, 94-110.

Des Combes, H.J., Caulet, J.P., Tribovillard, N., 2005. Monitoring the variations of the Socotra upwelling system during the last $250 \mathrm{kyr}$ : a biogenic and geochemical approach. Palaeogeography, Palaeoclimatology, Palaeoecology 223, 243-259.

Drake, N.A., Breeze, P. \& Parker, A., 2012. Palaeoclimate in the Saharan and Arabian Deserts during the Middle Palaeolithic and the potential for hominin dispersals. Quaternary International 300, 48-61.

Edgell, H., 2006. Arabian Deserts; Nature, origin and evolution. Dordrecht: Springer.

Emeis, K.C., Anderson, D.M., Doose, H., Kroon, D., Schulz-Bull, D., 1995. Sea surface temperatures and history of monsoon upwelling in the northwest Arabian Sea during the last 500,000 years. Quaternary Research 43, 355-361.

Enzel, Y., Amit, R., Dayan, U., Crouvi, O., Kahana, R., Ziv, B., and Sharon, D., 2008, The climatic and physiographic controls of the eastern Mediterranean over the late Pleistocene climates in the southern Levant and its neighboring deserts: Global and Planetary Change 60, 165- 192

Eshel, G., Farrell, B.F. 2000. Mechanisms of eastern Mediterranean rainfall variability. Journal of the Atmospheric Sciences 57, 3219-3232.

Farrant, A.R., Ellison, R.A., Thomas, R.J., Pharaoh, T.C., Newell, A.J., Goodenough, K.M., Lee, J.R., Knox, R.O., 2012. The geology and geophysics of the United Arab Emirates. In: Geology of the Western and Central United Arab Emirates, vol. 6. British Geological Survey, Keyworth, Nottingham. 371pp.

Farrant, A.R., Duller, G.A.T., Parker, A.G., Roberts, H.M., Parton, A., Knox, R.W.O, Bide, T., 2014. The dune story: developing a framework of dune accumulation in the northern Rub' al-Khali, Arabia. Quaternary International, in submission. 
Felis, T., Lohmann, G., Kuhnert, H., Lorenz, S.J., Scholz, D., Patzold, J., Al-Rousan, S.A., Al-Moghrabi, S.M., 2004. Increased seasonality in Middle East temperatures during the Last Interglacial period. Nature 429, 164-168.

Findlater, J., 1969. A major low level air current near the Indian Ocean during the northern summer. Quarterly Journal of the Royal Meteorological Society, 95, 362380 .

Finlayson, C., 2013. The Water Optimisation Hypothesis and the human occupation of the mid-latitude belt in the Pleistocene. Quaternary International 300, 22-31.

Finlayson, C., 2014. The Improbable Primate: How Water Shaped Human Evolution. Oxford University Press, Oxford.

Fisher, M., Membery, D., 1998. Climate. In: Ghazanfar, S.A., Fisher, M., (Eds.) Vegetation of the Arabian Peninsula. Kluwer Academic Publications, Dordrecht, pp. $5-38$.

Fleitmann, D., Matter, A., 2009. The speleothem record of climate variability in Southern Arabia. Comptes Rendus - Geoscience 341, 633-642.

Fleitmann, D., Burns, S.J., Neff, U., Mangini, A., Matter, A., 2003. Changing moisture sources over the last 330,000 years in Northern Oman from fluid-inclusion evidence in speleothems. Quaternary Research 60 (2), 223-232.

Fleitmann, D., Burns, S.J., Pekala, M., Mangini, A., Al-Subbary, A., Al-Aowah, M., Kramers, J., Matter, A., 2011. Holocene and Pleistocene pluvial periods in Yemen, southern Arabia. Quaternary Science Reviews 30, 783-787.

Foley, R.A., 1994. Speciation, extinction, and climatic change in hominid evolution. Journal of Human Evolution 26, 275-289.

Garrard, A., Harvey, C., Switzer, V., 1981. Environment and settlement during the upper Pleistocene and Holocene at Jubba in the Great Nefud, Northern Arabia, Riyadh. Atlal, 5, 137-148.

Glennie, K.W., Singhvi, A.K., 2002. Event stratigraphy, palaeoenvironment and chronology of SE Arabian deserts. Quaternary Science Reviews 21, 853- 869.

Govil, P., Naidu, P.D., 2010. Evaporation-precipitation changes in the eastern Arabian Sea for the last $68 \mathrm{ka}$ : implications on monsoon variability.

Paleoceanography 25, PA1210. 11.

Groucutt, H.S., Petraglia, M.D., 2012. The prehistory of the Arabian Peninsula: deserts, dispersals and demography. Evolutionary Anthropology 21 (3), 113-125.

Groucutt, H.S., Scerri, E.M.L., Lewis, L., Clark-Balzan, L., Blinkhorn, J., Jennings, R.P., Parton, A., Petraglia, M.D., 2014a. Stone tool assemblages and models for the dispersal of Homo sapiens out of Africa. Quaternary International, this issue. 
Groucutt, H.S., Shipton, C., Alsharekh, A., Jennings, R., Scerri, E.M.L., Petraglia, M.D., 2014b. Late Pleistocene lakeshore settlement in northern Arabia: Middle Palaeolithic technology from Jebel Katefeh, Jubbah. Quaternary International, this issue.

Grove, M., 2011. Change and variability in Plio-Pleistocene climates: modelling the hominin response. Journal of Archaeological Science 38, 3038-3047.

Grove, M., 2012. Amplitudes of orbitally induced climatic cycles and patterns of hominin speciation. Journal of Archaeological Science 39, 3085-3094.

Hemleben, C., Meischner, D., Zahn, R., Almogi-Labin, A., Erlenkeuser, H., Hiller, B., 1996. Three hundred eighty thousand year long stable isotope and faunal records from the Red Sea: Influence of global sea level change on hydrography. Paleoceanography 11(2), 147-156.

Higginson, M., Altabet, M.A., Murray, D.W., Murray, R.W., Herbert, T.D., 2004. Geochemical evidence for abrupt changes in relative strength of the Arabian monsoons during a stadial/interstadial climate transition. Geochimica et Cosmochimica Acta 68, 3807-3826.

Hijmans, R.J., Cameron, S.E., Parra, J.L., Jones, P.G., Jarvis, A., 2005. Very high resolution interpolated climate surfaces for global land areas. International Journal of Climatology 25, 1965-1978.

Hoffmann, G., Rupprechter, M., Rahn, M., Preusser, F., 2014. Fluvio-lacustrine deposits reveal precipitation pattern in SE Arabia. Quaternary International, in press

Honjo, S., and Weller, R.A., 1997. Monsoon winds and carbon cycles in the Arabian Sea. Oceanus 40(2), 24-28.

Ishikawa, S., Oda, M., 2007. Reconstruction of Indian monsoon variability over the past 230,000 years: Planktic foraminiferal evidence from the NW Arabian Sea openocean upwelling area. Marine Micropaleontology 63(3-4), 143-154.

Ivanochko, T.S., 2005. Sub-orbital variations in the intensity of the Arabian Sea monsoon. Ph.D. thesis, University of Edinburgh. Available at: http://www.era. lib.ed.ac.uk/handle/1842/760.

Jennings, R., Singarayer, S., Stone, E., Krebs-Kanzo, U., Khon, V., Nisancioglu, K.H., Parker, A.G., Parton, A., Groucutt, H.S., White, T.S., Drake, N.A., Petraglia, M.D., 2014. The greening of Arabia: multiple opportunities for human occupation of the Arabian Peninsula during the Late Pleistocene inferred from an ensemble of climate model simulations. Quaternary International, this issue, in submission

Jiang, H., J. T. Farrar, R. C. Beardsley, R. Chen, and C. Chen. 2009. Zonal surface wind jets across the Red Sea due to mountain gap forcing along both sides of the Red Sea. Geophysical Research Letters 36:L19605, 
Klöcker, R., Ganssen G., Jung, S.J.A., Kroon, D., Henrich, R., 2006. Late Quaternary millennial-scale variability in pelagic aragonite preservation off Somalia. Marine Micropaleontology 59, 171-183

Krbetschek, M.R., 2008. In: Uerpmann, H.-P., Jasim, S.A. (Eds.), The Natural Environ- ment of Jebel al-Buhais: Past and Present. Kerns Verlag, Tübingen, pp. 4345 .

Krishnamurti, T.N., Bhalme, H.N., 1976. Oscillation of a monsoon system, Part I: observational aspects. Journal of Atmospheric Sciences 33, 1937-1954.

Leuschner, D., Sirocko, F., 2003. Orbital insolation forcing of the Indian Monsoon - a motor for global climate changes? Palaeogeography, Palaeoclimatology, Palaeoecology 197, 83-95.

Lézine, A.M., Tiercelin, J.J., Robert, C., Saliège, J.F., Cleuziou, S., Inizan, M.L., Braemer, F., 2007. Centennial to millennial-scale variability of the Indian monsoon during the early Holocene from a sediment, pollen and isotope record from the desert of Yemen. Palaeogeography, Palaeoclimatology, Palaeoecology 243, 235-249.

Lisker, S., Vaks, A., Bar-Matthews, M., Roi, P., Amos, F., 2010. Late Pleistocene palaeoclimatic and palaeoenvironmental reconstruction of the Dead Sea area (Israel), based on speleothems and cave stromatolites. Quaternary Science Reviews 29, 12011211.

Machlus M., Enzel Y., Goldstein S. L., Marco S. and Stein M. (2000) Reconstructing low levels of Lake Lisan by correlating fan-delta and lacustrine deposits. Quaternary International 73/74, 137- 144.

Masson, V., Braconnot, P., Jouzel, J., de Noblet, N., Cheddadi, R., Marchal, O., 2000. Simulation of intense monsoons under glacial conditions. Geophysical Research Letters 27(12), 1747-1750.

McClure, H.A., 1976. Radiocarbon chronology of late Quaternary lakes in the Arabian Desert. Nature 263, 755-756.

McLaren, S.J., Al-Juaidi, F., Bateman, M.D., Millington, A.C., 2008. First evidence for episodic flooding events in the arid interior of central Saudi Arabia over the last 60 ka. Journal of Quaternary Science 24, 198-207.

Mellars, P., 2006. Why did modern human populations disperse from Africa ca. 60,000 years ago? A new model. Proceedings of the National Academy of Sciences 103 (25), 9381-9386.

Mellars, P., Gori, K.C., Carr, M., Soares, P.A., Richards, M.B., 2013. Genetic and archaeological perspectives on the initial modern human colonization of southern Asia. Proceedings of the National Academy of Sciences 110, 10699-10704.

Morcos, S. A. 1970. Physical and chemical oceanography of the Red Sea. Oceanography and Marine Biology 8, 73-202. 
Moumani, K., Alexander, J., Bateman, M.D., 2003. Sedimentology of the Late Quaternary Wadi Hasa Marl Formation of Central Jordan: a record of climate variability. Palaeogeography 191, 221-242.

Nair, R.R., Ittekkot, V., Manganini, S.J., Ramaswamy, V., Haake, B., Degens, E.T., Desai, B.N., Honjo, S., 1989. Increased particle flux to the deep ocean related to monsoons. Nature 338, 749-751.

Otto-Bliesner, B., S. Marshall, J. Overpeck, G. Miller, and A. Hu, 2006: Simulating Arctic climate warmth and icefield retreat in the last interglaciation. Science, 311, 1751-1753.

Parker, A.G., 2009. Pleistocene climate change in Arabia: developing a framework for Hominin dispersal over the last $350 \mathrm{ka}$. In: Petraglia, M.D., Rose, J.I. (Eds.), The Evolution of Human Populations in Arabia. Springer, London, pp. 39-51.

Parton, A., Farrant, A.R., Leng, M.J., Schwenninger, J-L., Rose, J.I., Uerpmann, H-P., Parker, A.G., 2013. An early MIS 3 pluvial phase in Southeast Arabia: Climatic and archaeological implications. Quaternary International, 300, 62-74.

Parton, A. 2013. Climate and landscape change in southeast Arabia from MIS 6 to MIS 3: Implications for the dispersal of hominin populations. Unpublished $\mathrm{PhD}$ thesis. Oxford Brookes University.

Pattan, J.N., Shane, P., Banakar, V.K., 1999. New occurrence of Youngest Toba Tuff in abyssal sediments of the Central Indian Basin. Marine Geology 155, 243-248.

Patzert, W. C. 1974. Wind induced reversal in Red Sea circulation. Deep-Sea Research 21, 109-121.

Petit-Maire, N., Carbonel, P., Reyss, J.L., Sanlaville, P., Abed, A., Bourrouilh, R., Fontugne, M., Yasin, S., 2010. A vast Eemian palaeolake in Southern Jordan $\left(29^{\circ} \mathrm{N}\right)$. Global and Planetary Change $72,368-373$.

Petraglia, M.D., Alsharekh, A.M., Crassard, R., Drake.,, N.A., Groucutt, H., Parker, A.G., Roberts, R., 2011. Middle Paleolithic occupation on a Marine Isotope Stage 5 lakeshore in the Nefud Desert, Saudi Arabia. Quaternary Science Reviews 30, 1555-1559.

Petraglia, M.D., Alsharekh, A., Breeze, P., Clarkson, C., Crassard, R., Drake, N.A., Groucutt, H.S., Jennings, R., Parker, A.G., Parton, A., Roberts, R.G., Shipton, C., Matheson, C., al-Omari, A., Veall, M.-A., 2012. Hominin dispersal into the Nefud Desert and Middle Palaeolithic settlement along the Jubbah Palaeolake, Northern Arabia. PLoS One 7 (11), e49840.

PrasannaKumar, S., Madhupratap, M. \& DileepKumar, M., 2001. High biological productivity in the central Arabian Sea during the summer monsoon driven by Ekman pumping and lateral advection. Current Science 81, 12 
Prell, W. L., and Van Campo, E., 1986. Coherent response of Arabian Sea upwelling and pollen transport to late Quaternary monsoonal winds. Nature 323, 526-528.

Prell, W. L., and J. E. Kutzbach. 1987. Monsoon variability over the past 150,000 years. Journal of Geophysical Research 92, 8411-8425.

Prell, W.L., Kutzbach, J.E., 1992. Sensitivity of the Indian monsoon to forcing parameters and implications for its evolution. Nature 360, 647-652.

Preusser F., Radies D., Matter A., 2002. A 160,000 year record of dune development and atmospheric circulation in Southern Arabia. Science 296, 2018-2020.

Preusser, F., 2009. Chronology of the impact of Quaternary climate change on continental environments in the Arabian Peninsula. Comptes Rendus Geoscience 341, 621-632.

Rabineau, M., Berne, S., Olivet, J. L., Aslanian, D., Guillocheau, F., Joseph, P., 2006. Paleo sea levels reconsidered from direct observation of the paleoshoreline position during Glacial Maxima (for the last 500,000 yr). Earth Planetary Science Letters 252, 119-137.

Radies, D., Preusser, F., Matter, A., Mange, M., 2004. Eustatic and climatic controls on the development of the Wahiba Sand Sea, Sultanate of Oman, 2004.

Sedimentology 51, 1359-1385.

Reichart, G. J., L. J. Lourens, and W. J. Zachariasse. 1998. Temporal variability in the northern Arabian Sea oxygen minimum zone (OMZ) during the last 225,000 years. Paleoceanography 13, 607-621.

Rixen, T., Guptha, M. \& Ittekkot, V., 2005. Deep ocean fluxes and their link to surface ocean processes and the biological pump. Progress in Oceanography 65, 240259

Robinson, L., Henderson, G. \& Slowey, N., 2002. U-Th dating of marine isotope stage 7 in Bahamas slope sediments. Earth and Planetary Science Letters 196, 175187

Rohling, E. J., K. Grant, M. Bolshaw, A. P. Roberts, M. Siddall, C. Hemleben, and M. Kucera. 2009. Antarctic temperature and global sea level closely coupled over the past five glacial cycles. Nature Geoscience 2, 500-504.

Rose, J.I., Usik.,, V.I., Marks, A.E., Hilbert, Y.H., Galletti, C.S., Parton, A., Geiling, J.M., Cerny, V., Morley, M.W., Roberts, R.G., 2011. The Nubian complex of Dhofar, Oman: an African Middle Stone Age Industry in Southern Arabia. PLoS ONE 6 (11), $1-22$.

Rosenberg, T.M., Preusser, F., Fleitmann, D., Schwalb, A., Penkman, K., Schmid, T.W., Al-Shanti, M.A., Kadi, K., Matter, A., 2011. Late Pleistocene pluvial periods in southern Arabia e windows of opportunity for modern human dispersal. Geology 39, $1115-1118$. 
Rosenberg, T., Preusser, F., Blechschmidt, I., Fleitmann, D., Jagher, R., Matter, A., 2012. Late Pleistocene palaeolake in the interior of Oman: a potential key area for the dispersal of anatomically modern humans out-of-Africa? Journal of Quaternary Science 27, 13-16.

Rosenberg, T.M., Preusser, F., Risberg, J., Plikk, A., Kadi, K.K., Matter, A., Fleitmann, D., 2013. Middle and Late Pleistocene humid periods recorded in palaeolake de- posits of the Nafud desert, Saudi Arabia. Quaternary Science Reviews 70, 109-123.

Rossignol-Strick, M., 1999. The Holocene climatic optimum and pollen records of sapropel 1 in the eastern Mediterranean, 9000-6000 BP. Quaternary Science Reviews 18, 515- 530.

Rosteck, F., Bard, E., Beaufort, L., Sonzogni, C., and Ganssen, G., 1997, Sea surface temperature and productivity records for the past $240 \mathrm{kyr}$ in the Arabian Sea: DeepSea Research II, 44, 1461-1480.

Saher, M. H., F. Rostek, S. J. A. Jung, E. Bard, R. R. Schneider, M. Greaves, G. M. Ganssen, H. Elderfield, Kroon, D., 2009. Western Arabian Sea SST during the penultimate interglacial: A comparision of $\mathrm{Uk} 37$ and $\mathrm{Mg} / \mathrm{Ca}$ paleothermometry. Paleogeography 24, PA2212

Sakai, K., Peltier, W., 1999. A dynamical systems model of the Dansgaard-Oeschger oscillation and the origin of the Bond cycle. Journal of Climate 12, 2238-2255.

Saraswat, R., Nigam, R., Weldeab, S., Mackensen, A., Naidu, P.D., 2005. A first look at past sea surface temperatures in the equatorial Indian Ocean from $\mathrm{Mg} / \mathrm{Ca}$ in foraminifera. Geophysical Research Letters 32, L24605

Scerri, E.M.L., Breeze, P., Parton, A., Groucutt, H.S., Stimpson, C., Clark-Balzan, L., Jennings, R.G., White, T., Petraglia, M.D., 2014. Landscape archives and Middle to Late Pleistocene human habitation in the Nefud Desert, Saudi Arabia. Quaternary International, this issue, (in press).

Scerri, E.M.L., Drake, N.A., Jennings, R., Groucutt, H.S., 2014. Earliest evidence for the structure of Homo sapiens populations in Africa. Quaternary Science reviews 101, 207-216.

Schuldenrein, J., Clark, G.A., 1994. Landscape and Prehistoric Chronology of WestCentral Jordan. Geoarchaeology 9, 31-55.

Schulz, E., Whitney, J.W., 1986. Upper Pleistocene and Holocene lakes in the An Nafud, Saudi Arabia. Hydrobiologia, 143, 175-190.

Schulz, H.E.A., von Rad, U., Erlenkeusser, H., 1998. Correlation between Arabian Sea and Greenland climate oscillations of the past 110,000 years. Nature 393, 54-57. 
Shane, P., Westgate, J., Williams, M., Korisettar, R., 1995. New geochemical evidence for the Youngest Toba Tuff in India. Quaternary Research 44, 200-204.

Shea, J.J., 2008. Transitions or turnovers? Climatically-forced extinctions of Homo sapiens and Neanderthals in the east Mediterranean Levant. Quaternary Science Reviews 27, 2253-2270.

Siddall, M., Smeed, D.A., Hemleben, C., Rohling, E.J., Schmelzer, I., Peltier, W.R., 2004. Understanding the Red Sea response to sea level. Earth and Planetary Science Letters 225(3-4), 421-434.

Siddall, M., Rohling, E.J., Blunier, T., Spahni, R., 2010. Patterns of millennial variability over the last $500 \mathrm{ka}$. Climate of the Past 6, 295-303.

Song, S.R., Chen, C.H., Lee, M.Y., Yang, T.F., Iizuka, Y., Wei, K.Y., 2000. Newly discovered eastern dispersal of the youngest Toba tuff. Marine Geology 167, 303312 .

Stokes, S., Bray, H.E., 2005. Late Pleistocene eolian history of the Liwa region, Arabian Peninsula. Geological Society of America Bulletin 117, 1466-1480.

Tisserand, A., Malaize, B., Jullien, E., Zaragosi, S., Charlier, K., Grousset, F., 2009. African monsoon enhancement during the penultimate glacial period (MIS 6.5 170 ka) and its atmospheric impact. Palaeoceanography 24, PA2220

Torfstein, A., Haase-Schramm, A. \& Waldmann, N., 2009. U-series and oxygen isotope chronology of the mid-Pleistocene Lake Amora (Dead Sea Basin). Geochimica et Cosmochimica Acta 73, 2603-2630

Trauth, M.H., Maslin, M.A., Deino, A.L., Strecker, M.R., Bergner, A.G.N., Duhnforth, M., 2007. High- and low-latitude forcing of Plio-Pleistocene East African climate and human evolution. Journal of Human Evolution 53, 475-486.

Trommer, G., M. Siccha, E. J. Rohling, K. Grant, M. T. J. van der Meer, S. Schouten, U. Baranowski, and M. Kucera. 2011. Sensitivity of Red Sea circulation to sea level and insolation forcing during the last interglacial. Climate of the Past 7, 941-955.

Vaks, A., Bar-Matthews, M., Ayalon, A., Schilman, B., Gilmour, M., Hawkesworth, C.J., Frumkin, A., Kaufman, A., Matthews, A., 2003. Paleoclimate reconstruction based on the timing of speleothem growth and oxygen and carbon isotope composition in a cave located in the rain shadow in Israel. Quaternary Research 59, 182-193.

Vaks, A., Bar-Matthews, M., Ayalon, A., Frumkin, A., Dayan, U., Halicz, L., Almogi-Labin, A., Schilman, B., 2006. Paleoclimate and location of the border between Mediterranean climate region and the Saharo-Arabian Desert as revealed by speleothems from the northern Negev Desert, Israel. Earth and Planetary Science Letters 249, 384-399 
Vaks, A., Bar-Matthews, M., Ayalon, A., Matthews, A., Halicz, L., and Frumkin, A., 2007. Desert speleothems reveal climatic window for African exodus of early modern humans. Geology 35, 831-834.

Vaks, A., Bar-Matthews, M., Matthews, A., Ayalon, A., Frumkin, A., 2010. MiddleLate Quaternary paleoclimate of northern margins of the Saharan-Arabian Desert: reconstruction from speleothems of Negev Desert, Israel. Quaternary Science Reviews 29, 2647-2662.

Van Campo, E., Duplessy, J.C., Rossignol-Strick, M., 1982. Climatic conditions deduced from a 150-kyr oxygen isotope-pollen record from the Arabian Sea. Nature 296, 56-59.

Vries, A.J. et al., 2013. Extreme precipitation events in the Middle East: Dynamics of the Active Red Sea Trough - Vries - 2013 - Journal of Geophysical Research:

Atmospheres - Wiley Online Library. Journal of Geophysical Research: Atmospheres $118,7087-7108$.

Waldmann, N., Torfstein, A., Stein, M., 2010. Northward intrusions of low- and midlatitude storms across the Saharo-Arabian belt during past interglacials. Geology, 38(6), 567-570.

Weyhenmeyer, C.E., Burns, S.J., Waber, H.N., Aeschbach-Hertig, W. Kipfer, R., Beverle, R., Loosli, H., Matter, A., 2000. Cool glacial temperatures recorded by noble gases in a groundwater study from Northern Oman. Science 287, 842-845.

Whitney, J.W., 1983. Erosional history and surficial geology of western Saudi Arabia (Technical record USGS-TR-04-1). Saudi Arabian Deputy Ministry for Mineral Resources, 1-90

Williams, M.A.J., Pal, J.N., Jaiswal, M., Singhvi, A.K., 2006. River response to Quaternary climatic fluctuations: evidence from the Son and Belan valleys, north central India. Quaternary Science Reviews 25, 2619-2631.

Wood, W.W., Imes, J., 1995. How wet is wet? Precipitation constraints on late Quaternary climate in the southern Arabian Peninsula. Journal of Hydrology 164, 263-268.

Wood W.W., Rizk, Z.S., Alsharhan, A.S., 2003. Timing of recharge, and the origin, evolution, and distribution of solutes in a hyperarid aquifer system. In: Alsharhan AS, Wood WW, (Eds.). Water resources perspectives: evaluation management and policy. Elsevier, Amsterdam p. 295-312.

Yuan, D., Cheng, H., Edwards, L., Dykoski, A., Kelly, M., Zhang, M., Qing, J., Lin, Y., Wang, Y., Wu, J., Dorale, J.A., An, Z., Cai, Y., 2004. Timing, duration, and transitions of the last interglacial Asian monsoon. Science 304, 575-578.

Ziegler, M., Tuenter, E., Lourens, L., 2010a. The precession phase of the boreal summer monsoon as viewed from the eastern Mediterranean (ODP Site 968). Quaternary Science Reviews 29, 1481-1490 